\title{
Creating a European public space: practitioners' dream, academic nightmare
}

Citation for published version (APA):

Shackleton, M. E. F. (2012). Creating a European public space: practitioners' dream, academic nightmare. Maastricht University. https://doi.org/10.26481/spe.20121206ms

Document status and date:

Published: 06/12/2012

DOI:

10.26481/spe.20121206ms

Document Version:

Publisher's PDF, also known as Version of record

\section{Please check the document version of this publication:}

- A submitted manuscript is the version of the article upon submission and before peer-review. There can be important differences between the submitted version and the official published version of record.

People interested in the research are advised to contact the author for the final version of the publication, or visit the DOI to the publisher's website.

- The final author version and the galley proof are versions of the publication after peer review.

- The final published version features the final layout of the paper including the volume, issue and page numbers.

Link to publication

\footnotetext{
General rights rights.

- You may freely distribute the URL identifying the publication in the public portal. please follow below link for the End User Agreement:

www.umlib.nl/taverne-license

Take down policy

If you believe that this document breaches copyright please contact us at:

repository@maastrichtuniversity.nl

providing details and we will investigate your claim.
}

Copyright and moral rights for the publications made accessible in the public portal are retained by the authors and/or other copyright owners and it is a condition of accessing publications that users recognise and abide by the legal requirements associated with these

- Users may download and print one copy of any publication from the public portal for the purpose of private study or research.

- You may not further distribute the material or use it for any profit-making activity or commercial gain

If the publication is distributed under the terms of Article $25 \mathrm{fa}$ of the Dutch Copyright Act, indicated by the "Taverne" license above, 
Prof. dr. Michael E.F. Shackleton

Faculteit der Cultuur- en Maatschappijwetenschappen

Creating a European Public Space: Practitioners' Dream, Academic Nightmare 
Creating a European Public Space:

Practitioners' Dream, Academic Nightmare

Inaugural lecture

delivered on the occasion of his acceptance of the position of Extraordinary Professor 'European Institutions' in the Faculty of Arts and Social Sciences

Maastricht, 6 December 2012

Dr. Michael Shackleton 


\section{Introduction}

Dear Rector Magnificus, dear Professors, dear colleagues, dear family and friends, thank you for attending my inaugural address today. It is a particular pleasure and privilege to be here as I have spent such a small part of my career since the 1970s in the academic world. The granting of this professorship represents for me an acknowledgement that there is a space between the very different worlds of academics and practitioners where both sides can meet to their mutual advantage.

On each side of the divide there are those who would disagree: many of my former colleagues in the European Parliament dismiss academic discussion as over theoretical and without relevance to their everyday work and in the university world I have regularly heard the refrain that understanding the world properly requires distance from the contagion of the practitioner. I want to show you that both these views are open to challenge.

\section{The Practitioners' Dream}

Let me begin with Jose Manuel Barroso, President of the European Commission. Nearly three months ago on 12 September he gave his third State of the Union address to the European Parliament and included the following passage:

"I would like to see the development of a European public space, where European issues are discussed and debated. We cannot continue trying to solve European problems just with national solutions.

An important means to deepen the pan-European debate would be the presentation by European political parties of their candidate for the post of Commission President at the European Parliament elections in 2014. This can be done without a Treaty change and would be a decisive step to make the possibility of a European choice offered by these elections even clearer. I call on the political parties to commit to this step and thus to further Europeanise the European elections".

This proposal is not new: it was widely discussed before the 2009 European elections. Simon Hix at LSE included an entertaining scenario for such a European Commission President contest in his book "What's Wrong with the European Union and How to Fix It". The plausibility of his suggestion that such a contest might lead to the election of a Swedish woman Socialist, called Margot, was never put to the test. The European People's Party (EPP) did give its backing to President Barroso for a second term in advance of the 2009 elections but no other candidates were put forward, making a contest of the kind suggested by Hix impossible. 
The situation today is very different. The Lisbon Treaty saw the addition of a small but significant phrase. As before, the European Council is called upon to propose a candidate for President of the Commission but in future it has to do so, "taking into account the elections to the European Parliament". There is no unanimity as to what the additional phrase means but as ever in the EU, there is no shortage of ideas. One of them is changing the way the Commission President is elected, a suggestion that is winning increasing backing.

The position of President Barroso has now been formally backed by a very large majority in the European Parliament at its session of 22 November. Already before that support had been growing in the main European political parties, in particular in the European People's Party (EPP) and the Party of European Socialists (PES). They are both very active in establishing procedures for finding candidates who will present and defend the party manifestoes in the period leading up to May or June 2014. The EPP is due to hold a summit in Cyprus in January 2013 at which it will consider the profile of potential EPP candidates and the way it will choose between them. Possible names, such as the Polish Prime Minister, Donald Tusk, are already circulating. In the PES, back in December 2011, there was agreement at a party Congress in Lisbon on a detailed procedure which will lead to the selection of their candidate in December 2013. In other words, we can confidently expect the 2014 elections to the European Parliament to be complemented by a competition between potential future Presidents of the European Commission.

It is an institutional innovation that has considerable attractions for many practitioners. In the European Parliament there is the recognition that this may be a way in which the decline in average turnout that has marked each successive election since 1979 can at last be halted. A survey carried out for the Parliament earlier this year found that $54 \%$ across the EU would be more likely to vote at the 2014 elections if the European party alliances put up candidates for Commission President. Even in the UK, you may be surprised to learn, the figure was only five per cent beneath this European average. In other words, the Parliament can dream of reversing a trend that has beset it for more than 30 years.

More generally, it is a change that is seen as having the potential to alter the character of European elections and their impact on the electorate. It has always been very difficult for voters to see the connection between their vote and outcomes in the European Union. Noone today seriously contests that the Parliament can have a significant impact on the content of EU legislation but it is very difficult to trace that impact back to anything that was said by the different political parties during the European election campaign. The party manifestoes have traditionally been the product of delicate compromises between national parties with often divergent positions. The result has been that the differences between European parties 
have been obscured. Instead we have witnessed European elections that have been largely hijacked by national political conflicts.

The proposed change is designed to alter the dynamics of European elections. The candidates for Commission President would be obliged to present their visions of Europe in advance of the elections, rather than to present them afterwards in the weeks leading up to their election by the Parliament. I doubt whether many people in this room read - and if they read it, can remember - the programme presented by President Barroso in the summer of 2009 when he sought re-election in the Parliament. In 2014 his successor will have to present an equivalent document to the general public across the whole European Union in advance of the Parliament elections, will be obliged to defend it in the face of competing programmes of other candidates and will find her or himself reminded of what they wrote during their five year period of office. The accountability of the Commission President could therefore be significantly reinforced, making it more difficult to argue that Europe is run by unelected bureaucrats.

However, it is a scenario that has been far from universally welcomed. Jacques Delors, for example, one of Barroso's illustrious predecessors as Commission President, has argued strongly against it. He has claimed that it risks undermining the separation of powers between the Commission and the Parliament and that it would subject the former much more directly to the will of a political majority in the latter. As a result the Community method would be subverted in the name of parliamentary government. Others have taken a more hardnosed, realist approach, suggesting it is simply not practical and will not work: candidates will remain invisible at the national level, national political parties will not devote resources to promoting their candidacies and Heads of State and Government in the European Council will not feel bound by the results when it comes to nominating a candidate for approval by the Parliament after the elections have taken place. Others again have argued that the chief issue of accountability in the EU lies not in the Commission but rather in the development of the powers of the European Council and the European Central Bank, neither of which are subject to effective, collective democratic supervision. The drift to what is referred to as "executive federalism" makes changing the method of selection of the Commission President an irrelevant sideshow.

Here I do not wish to linger on the validity of these various objections to the Barroso dream: we are sure to hear them ever more loudly in the coming months. Instead I want to ask what such an institutional change looks like from an academic point of view. 


\section{The Academic Nightmare}

Let us suppose that the election of the President of the Commission via the 2014 European elections did indeed manage to generate a European debate and to create a vibrant European public space, as President Barroso suggests. What would be the reaction of students of European integration? Well, I think that for many it might be a nightmare rather than a dream. It would suggest that a major element of the argument about the future of the EU had been miraculously resolved and could be set to one side, making it necessary to develop completely different areas of inquiry. Academic papers would have to be abandoned; books rewritten and career trajectories altered.

In fact, we all recognise very well that this is not going to happen. The reason for this is simple: a European Public Space is not something that can be found by rigorous analysis or be brought into being by an institutional fix; it is not a place that is out there to be discovered by SatNav or an object to be created, if only we work hard enough at it. Rather it is an idea, an idea about which people disagree, one that academics often describe as "essentially contestable". We can never reach a definitive view of its nature but need to compare competing conceptions about the necessity, possibility or desirability of establishing such a space. There is no conclusive proof that such a space is necessary, possible or desirable, only arguments in favour or against that are found more or less compelling at any point in time. This may be galling for the practitioner expecting her or his dream to be realised but it makes for a much more vigorous and stimulating debate in which both practitioners and academics can take an active part.

A good point of departure for this debate is to offer some historical perspective. Writers, such as the German philosopher, Jürgen Habermas, and the Dutch lawyer and historian, Geert Mak, have pointed to the importance of the coffee house in national political life. These were the places where ordinary citizens could meet openly to debate the issues of the day and to challenge public authorities to explain and justify their actions. The effectiveness of this challenge was visible in the attempts of the authorities to limit or close down the coffee houses, as Charles II did in England in the 1670s. These attempts failed; instead the coffee houses came to play a vital part in creating a democratic public sphere.

What is the relevance of this to the EU? Mak argues that one of the problems of the EU is that "there has never been a European coffee house, an "agora", a place where Europeans can form their opinions, give birth to new ideas, and test their views". Such debate as there is remains restricted to a very small elite of decision-makers and opinion-formers. Habermas suggests we need to be able to compare what happens with his definition of a European public sphere as "a public political sphere which enables citizens to take positions at the same 
time on the same topics of the same relevance". Indeed he used this definition to claim that we could witness the emergence of a European public space on 13 February 2003, a day when millions across Europe marched against the Iraq war. This claim has been much derided, not least because we have witnessed no equivalent events since that time, but it brought to the fore recognition of the need to identify criteria that enable one to talk about the existence of such a public space.

Such a discussion of criteria does not seem relevant or important to all writers. Some, like the American, Andrew Moravcsik, have argued that the European Union can operate perfectly well without a public space. In their view, the European Union does not need such a space because it does not suffer from what is often termed a "democratic deficit". The Union remains essentially a creature of the Member States and as they are all adjudged democratic, it is unnecessary to envisage a democratic overlay at the European or supranational level. Essentially the Union provides a mechanism for the Member States to manage their economic interdependence by the development of common rules. Hence there is no need to worry about a lack of politicisation and debate beyond the Brussels world. Indeed such politicisation would be likely to lead to the undermining of the system by making it impossible to continue making policy through the consensus mechanisms that are central to the Brussels machinery.

Such an approach has some overlap with what is often referred to as the Monnet method, the idea that policy making should be concentrated in the hands of experts looking for the most efficient solutions to any problem, in the hope and expectation that success would lead to the gradual expansion of the areas subject to this way of coming to agreements. It is a point of view that I have often heard in Brussels from officials who complain about the interference of MEPs and their tendency to complicate the work of experts. Such officials will definitely not be enthusiastic about the Barroso proposal!

However, this position is one that has to my mind lost ground in the recent past. The socalled "permissive consensus" that allowed policy makers to act without undue concern as to its impact on the electorate has all but disappeared. It has become much more difficult to insulate policy making from the wider political process, for the EU to make policy without politics, when the public beyond starts to attribute its difficulties to the results of those policies. Street protests across much of Southern Europe have been marked by people complaining not only about the actions of their own governments but also those of policy makers in Brussels and Frankfurt. Such protests have inevitably provoked a debate about the legitimacy of the decisions taken and the mechanisms by which those who took them can be held to account. Is it not therefore essential that we have somewhere a public arena, a "coffee house", where the policies agreed at EU level can be discussed and debated? 
You might think that the answer to this question was self-evident, that all would agree that a "coffee house" was needed: you would be mistaken. There is a strong second strand of academic opinion that holds that the creation of a European public space, even if theoretically desirable, is in fact an impossible dream. Thus Ralf Dahrendorf, a man who knew the worlds of theory and practice equally well, wrote:

"We have no European public space in which we can seriously debate in a democratic way. The nation state is the only context in which representative, parliamentary democracy, based on debate, can work. Europe is not democratic".

Such a point of view directly contradicts the provisions on democratic principles of the Treaty on European Union and the statement in Article 10 that "the functioning of the Union shall be founded on representative democracy". It seems to condemn us to remain locked in our national worlds and to oblige us to consider the idea of a European coffee house as a contradiction in terms. For these very reasons it holds a strong appeal for nationalist opinion in many EU states, not least in my own country.

However, it obliges us to consider why it is that there can be no "serious debate", in Dahrendorf's words, across the countries of the European Union? The thesis depends on at least two assumptions that should be questioned: first, that Europeans have no sense of identity beyond the nation state and second, that they have no means of communicating in any serious way across borders.

It is certainly true that very few Europeans feel exclusively European; I doubt that even a poll of Erasmus students would suggest that a single European identity is emerging. However, as the European Parliament survey I mentioned earlier points out, across the EU there is a rough balance between those who feel that they belong exclusively to their nation state and those who feel that they belong to Europe as well as belonging to their nation state. The figures are $44 \%$ and $43 \%$ respectively. These figures conceal considerable variation across countries. In the UK, for example, $65 \%$ feel exclusively national and just $27 \%$ include a sense of Europeanness in their national identity, whereas here in the Netherlands the equivalent figures are almost a mirror image of those for the UK, with 34\% feeling exclusively national but $52 \%$, also considering that they are European. The implications of this phenomenon, sometimes described as European identity-lite, are much disputed. There is good empirical evidence to suggest that the inclusive nationalists are more inclined to support further European integration but how much integration is unclear. Does it offer a sufficient basis, for example, for the kind of redistributive policies that are found at national level? Most would consider this to be unlikely; so-called "solidarity with strangers" remains rather thin at European level. However, why should this level of identification with Europe not be enough to 
permit the development of a European public space at least in those countries where exclusive nationalism is relatively weak?

One response to that question is to say that whatever Europeans may feel about their identity, they do not have the means to communicate effectively across national boundaries: they do not speak the same language, they do not have Europe-wide media available to them and they do not have a common European perspective. The assumptions that lie behind this response are far from self-evident.

The lack of a common language seems a weak basis for denying the possibility of communication. Who would argue that there can be no public space in Switzerland simply on the grounds that four languages are spoken in different parts of the country? And as Thomas Risse has pointed out in his book "A Community of Europeans?", a Westerner who lands on an unknown island and meets indigenous people whose language she or he does not understand can develop meaningful communication by a process of trial and error. National linguistic barriers do not have to disappear for people to be able to understand each other.

The absence of a common European media is something that is often deplored by those who see the need for a European public space as much as by those who consider such a space is impossible to create. The former have been dismayed by the limited success of initiatives such as Euronews and the failure of ventures such as The European newspaper. And yet is it really necessary to argue that Europeans cannot communicate with each other, because they insist on continuing to read Le Monde, El Pais and The Guardian and to watch ARD, BBC and RaiUno? It may be it is more difficult to transcend national cultural barriers but are the differences between Germans and the Dutch so much greater than the differences between Prussians and Bavarians that they cannot understand each other? Mutual understanding arises by overcoming such cultural barriers through communication, not by assuming such barriers do not exist. It is the extent to which national media are Europeanised rather than whether a European media can be created that constitutes the measure of a European public space.

As for the idea that a common European perspective is required for communication across frontiers, this seems to belie the importance of recognising that people disagree about the direction Europe should take just as they disagree about national priorities. As in the coffee shops of the $17^{\text {th }}$ and $18^{\text {th }}$ centuries, contestation is a central element of the creation of a vibrant public sphere. Consensus may be where one ends up but cannot itself be the driving force of a political system.

Risse suggests that instead of looking for a common perspective, we should rather consider how far commentators in different countries use the "same criteria of relevance" in observing 
European issues. This goes beyond the Habermas's claim that the same issues need to be discussed at the same time across borders. It involves observing empirically the extent to which national media refer to what other countries say with regard to European issues, the degree to which foreigners are perceived as legitimate participants in national debates of common European concern and whether issues are addressed as concerning Europeans as a whole, rather than individual countries. In Risse's view there is reasonable evidence to conclude that particularly for issues that are highly sensitive politically, and in most of mainland Europe (not, I am afraid, the UK), the criteria of relevance are converging and thereby contributing to the development of a European public space.

These conclusions remain tentative and certainly do not close the argument. Rather their importance lies in contradicting much of the received wisdom. First, they contest the very common claim that the nation state is the "natural container of the public sphere". There is no need to accept such a deterministic view. Second, contestation and polarisation of opinion are crucial conditions for the emergence of a public sphere, rather than indicators of its absence. There is no need to fear challenges from society to the EU's institutional framework: they are not indicators by themselves that the system is dysfunctional. Third, a European public space is something that can be gradually constructed over time, by the interaction of European citizens and their evolving attitudes towards European identity. We should not expect it to emerge from single Treaty changes, or indeed from a simple "institutional fix" of the kind proposed for the 2014 European elections. So the nightmare of the European public space dilemma disappearing in 2014 can be safely put to one side.

\section{Bringing the two worlds together}

What conclusions can we draw from this discussion of changes to the system of election of the President of the Commission and the review of some of the academic debate about a European public space? Do they together help in finding a common area between the questions raised by academics and the preoccupations of practitioners, as I suggested at the beginning? Do the two sides remain locked in different worlds with little to learn from each other? I would suggest four points of contact.

First, the Barroso proposal reflects a readiness and ability of European institutions to adapt, something that academics need to keep abreast of and acknowledge. In particular, it underlines a changing perception of the way in which a European public space could be created. That change may not have been directly influenced by academic debate but it reflects an important strand of that debate. Consider how very different the discussion in the EU institutions is now compared with that which took place after the 2005 referenda on the European Constitution. The no votes here in the Netherlands and in France prompted much 
soul-searching in Brussels and convinced many that the lesson to be learnt was the need for better communication with European citizens. The assumption was that attitudes towards the EU would change if the institutions communicated better and considerable resources were brought to bear to make this possible.

I was myself a participant in this process inside the European Parliament when I assumed administrative responsibility for the establishment of europarltv, the Parliament's webTV channel. We wanted this channel to provide viewers with the opportunity to follow and gain an understanding of the institution that they had elected, without depending on the media in the Member States, which had little interest in or sympathy for the Parliament and were hardwired to reflect national preoccupations. We even made a bigger claim for the channel, including in the first paragraph of its Editorial Charter, the statement that "the channel is designed to contribute to the democratisation of the European Union and to the development of a European public space".

Whatever the merits of the channel, and I am naturally not a neutral on the subject, I am doubtful that we would repeat today the claim that it can contribute in a significant way to a European public space. It reaches relatively few viewers and there is little evidence to suggest that it generates the kind of debate and discussion across Europe that are central to such a space. The Parliament's Facebook and Twitter accounts, the former with approaching half a million "Friends", have been much more successful in this respect. The europarltv charter was a product of a particular time and the change since then is well illustrated by the Barroso proposal. Practitioners realise that it is not as easy as we thought to create a European public space.

Second, the evidence provides an opportunity for both sides to think critically about the criteria necessary for a European public space to emerge. The academic debate underlines the importance for EU practitioners not to overlook the relevance of the national, rather than the European, level. There is little or no evidence to support the idea that Europeans are adopting a European identity or that they are likely to communicate across borders through exclusively European media. If this is right, then the Barroso proposal needs to become part of the debate at national level and not simply be discussed in Brussels and Strasbourg. It needs to escape the traditional insulation of EU decision making from mass politics, something which is so deeply rooted in the way the Union works.

My own experience within the world of codecision, now known less helpfully as the Ordinary Legislative Procedure, provides evidence of this state of affairs. MEPs participate in the policy-making process and contribute in significant ways to shaping EU laws but it remains a process that is all but invisible to the general public. Indeed this trend has become even more marked with the increase in the number of agreements at first reading early in the procedure, 
offering very limited opportunities for public debate. What is at stake remains very distant from the national world, except for those very close to the issues.

This distance between voters and the institutions matters and needs to be addressed, particularly as the stakes rise and voters attribute their economic woes to the EU. In such circumstances, it becomes all the more important to have an arena beyond the narrow Brussels world where there can be a debate about how to respond to the crisis. The academic literature underlines very clearly the need for that arena to be as much in national societies as in Brussels.

One feature of the academic literature is that it tends to underestimate the relevance and importance of the institutional debate: the output of institutions is often given greater weight than how they work. It is certainly reasonable to argue that an "institutional fix", such as that proposed for 2014, will not in itself generate a European public space. However, I would argue that some form of institutional change is necessary, even if not sufficient, for the emergence of such a space. The difficulty is identifying which adaptation out of the many envisaged can bring about real change.

New Treaty rules may not achieve as much as is sometimes claimed for them but they do alter the framework within which practitioners act and think, enabling them to respond differently to the circumstances that surround them. This is what happened, for example, with the introduction of majority voting and the incentive it gives for finding agreements, whilst respecting the position of minorities. And who is to say that this new institutional fix, made a clearer option by Treaty change, will not alter the way the Union operates and the kinds of policy it adopts? It is not at all fanciful to imagine that as part of the next revision of the Treaties, the posts of President of the European Council and of President of the European Commission could be merged (in the way we now have a single High Representative for Foreign Affairs who sits both in the Commission and in the Council). If so, we might move to a single elected EU head whose mode of selection would surely be influenced by the 2014 experiment.

Third, the Barroso proposal provides an ideal testing ground for many of the ideas that are discussed in the academic literature. It provides a fertile research agenda for students here at Maastricht over the next couple of years to see if we can indeed witness the development of a stronger European public space. A few questions from such an agenda will suffice to make the point:

How will national parties across the EU respond to the candidates put forward by the European parties? What, for example, will the British Labour party say if a German PES 
candidate for Commission President argues for a financial transaction tax? Will it ignore her or him or modify its own position?

What attention will national media pay to the different candidates, especially when in most countries they will be "foreigners"? Will there be debates between the candidates designed to bring out their different conceptions of the future of Europe?

Will the candidates themselves be willing to profile themselves in a way that shows up their differences? Or will they feel themselves to be bound by rather bland manifestoes drawn up by the European parties? And how will they relate to the MEP candidates of their political family?

How will national governments respond? Are we right to assume that they will be very reluctant to see a European public space emerge as it will create something over which they have very limited control, what I might call the Charles II syndrome?

And what about citizens? Will they be more willing to vote at the European elections because of this change, as the poll conducted for the European Parliament suggests they will? Will it change their attitudes to the EU? Will it enable them to see the importance of the EU for their future? Will it make them feel that they have a stronger input into what is decided at EU level?

Such a wide range of questions surely provides an excellent reason to believe that there is plenty of room for academics and practitioners to come together to share their contrasting perspectives.

A final issue relates to the question of values and concerns all of us. What I myself have described as an "institutional fix" is in fact more than that. It reflects a belief that democratic accountability within the EU is an important value in itself and that it must mean more than simply casting a vote for one party or the other. It surely must involve giving Europeans a meaningful choice about the kind of Europe they wish to inhabit, the sort of policies they want to be pursued and the nature of the politicians they would like to carry those policies through.

The need to give more concrete meaning to this idea of accountability has never been more pressing. The EU as a whole is faced by a major test. Can it manage its very diverse composition in a way that is perceived as legitimate by its citizens? Can it make a reality of the slogan "Unity in Diversity"? Can the institutions generate the kind of policies that win popular support? Whether or not one considers it useful to change the way in which the Commission President is elected, whether or not we are academics or practitioners, we are all confronted with a challenge to our imagination, to conceive of a framework that can help to 
answer these questions. It is a challenge that all should be ready to take up inside the European coffee house. I hope to see you all there.

\section{Words of thanks}

I feel very privileged to have been given the opportunity to share my experiences as an official of a European institution with the students of this university. I have already been coming here for a number of years and have watched as the European Studies department has grown into probably the largest such department in the world. The range of nationalities of the students - even I am pleased to say, a growing number of British students - makes one feel that the European public space is here already in Maastricht. I have had a chance to get to know the coming generations of practitioners and academics and to consider with them how very different the world will be for them than it has been for me. I look forward to continue to be able to play this role in the future, acting as a kind of "pracademic", with sensitivity to the concerns of both sides of the divide.

I have consistently felt strong support from Rein, as Head of the Faculty, who has encouraged me to look for all kinds of different ways of engaging with the university, here in Maastricht and beyond. I have also enjoyed immensely my contact with Tannelie, whose project on the Politics of Informing has given me a chance to put on record some of my experiences in establishing europarltv.

I would not be here at all if it were not for Sophie Vanhoonacker. She has encouraged me for many years to work with her in introducing students to the world of practitioners, setting up "The Practicalities of Policy-Making" course which has continued to prove very popular. It is also with her that we have established the Jean Monnet Lecture Series, with four lectures per year, given mostly by those directly involved in EU affairs. It is now in its fifth edition so we will have reached twenty speakers by the spring of next year. She has also given me a chance to be involved in the INCOOP research project which has allowed me to share my experience with excellent $\mathrm{PhD}$ candidates. Thank you, Sophie, for encouraging me always to want to find the time to come here when the daily pressure of work would have made it so much easier to stay at home, whether in Brussels, London or Oxford.

This is also an opportunity for me to thank those who have accompanied me on my journey through the European Parliament over thirty years. It is hard to underestimate how much I gained from working with Steve Clark, one of our contributors to the Jean Monnet Series. $\mathrm{He}$ was a constant support to me in the difficult days of setting up europarltv and ten years earlier, I remember well him displaying his skills as a master wordsmith as we produced the report of the Parliament's first committee of inquiry in the middle of the night. 
I have also been lucky enough to work with Richard Corbett and Francis Jacobs, the former now an adviser to Herman Van Rompuy, the latter head of the European Parliament Information Office in Dublin. Over twenty years we have worked together to produce eight editions of our book "The European Parliament". The book has been the expression of our common desire to contribute to public understanding of a much misunderstood institution. It has also testified to the strong bonds of friendship between us that have enabled us to overcome our different perspectives and writing styles.

And for fifteen years, half of my career. Brenda James and I worked together in adjoining offices in the Parliament and became good friends. It is hard to underestimate the importance of having someone nearby that can give you good advice, share confidences and best of all, enjoy a joke with you.

I would also like to thank my best man, Gottfried Thesen, for originally persuading me to go and work for the Parliament. At the time I had academic tenure in the UK and most people considered my move to Luxembourg to be the height of recklessness. I do not regret taking his advice to become a practitioner.

Many of those I have mentioned are here today but unfortunately, my parents cannot be. My father would, I am sure, have appreciated the opportunity to see where all the support he gave me in my younger days had brought me and to admire this fine gown. My mother is still there in the UK to encourage me and to remind me of my German background, which has been so important in shaping my belief in the importance and value of the European Union.

My daughters, Katie and Lucy, also are not here but they have played a vital part in my life, reminding me that the outward signs of success can never match the inward satisfaction of seeing your children grow up and begin to make their mark in the world.

Finally, I want to thank you, Jan, for your unstinting love and support over the last 25 years. It has not always been easy for you as I struggled to reconcile work, the family and yet another edition of "The European Parliament". Despite these tensions, you were always willing to give of your time to look at my work and to stop me being too verbose, too willing to produce another subordinate clause. I hope that you feel that I have benefitted today from that advice. 


\section{Bibliography}

The text of the debates of the European Parliament can be found online under the Plenary rubric of the institutions's website at www.europarl.europa.eu; the Parliament's webTV channel can be located at www.europarltv.eu: the activities of the EPP and PES parties are detailed on their websites, $\underline{w w w . e p p . e u}$ and www.pes.eu.

Bijsmans, P. (2011) Debating Europe: Reflections on EU Affairs in the Public Sphere, Maastricht: Maastricht University Press

Clark, S. and Priestley, J. (2012) Europe's Parliament: People, Places, Politics, London: John Harper

Corbett, R., Jacobs, F. and Shackleton, M., (2011) The European Parliament, London: John Harper ( $8^{\text {th }}$ edition)

Delors, J. "La gouvernance économique dans I'Union européenne: présent, passé et futur", Lecture delivered at Sciences Po in Paris on 16 April 2012 to commemorate 50 years of the Journal of Common Market Studies, available at www.uaces.org/delors

Enzensberger, H.M. (2011) Brussels, the gentle monster or the Disenfranchisement of Europe, London: Seagull Books

European Parliament (2012) Two years to go to the 2014 European elections, Directorate General for Communication, Eurobarometer, EB/EP 77.4

Habermas, J. (2012) The Crisis of the European Union, Cambridge: Polity Press

Hix, S. (2008) What's Wrong with the European Union and How to Fix It, Cambridge: Polity Press

Huber, K. and Shackleton, M. (2013) 'Codecision: A Practitioners' View from Inside the Parliament" in Journal of European Public Policy, forthcoming

Leconte, C. (2010) Understanding Euroscepticism, Basingstoke: Palgrave Macmillan

Mak, G. (2007) In Europe: Travels through the Twentieth Century, London: Harvill Secker

Moravcsik, A. (2002) "In Defence of the 'Democratic Deficit': Reassessing Legitimacy in the European Union", Journal of Common Market Studies, 40, no.4: 603-24 
Peterson, J. and Shackleton, M. (eds.) (2012) The Institutions of the European Union, Oxford: Oxford University Press

Risse, T. (2010) A Community of Europeans? Transnational Identities and Public Spheres, Itaca and London: Cornell

Schmidt, V. (2006) Democracy in Europe: The EU and National Polities, Oxford: Oxford University Press

Shackleton, M. (2005) "Parliamentary Government or Division of Powers: Is the Destination Still Unknown?" in Jabko, N. and Parsons, C. (eds.) The State of the European Union (Vol.7): With US or Against US? European Trends in American Perspective, Oxford: Oxford University Press, 123-41

Shackleton, M. (2011) 'The European Parliament: the major winner of the Lisbon Treaty?' in The European Union after the Lisbon Treaty, edited by Thomas Christiansen, Michael Shackleton and Sophie Vanhoonacker, Maastricht Monnet Lecture Series Vol.3, 38-48

Shackleton, M. (2013) "The European Parliament 'on air"' in The Politics of Informing, Basingstoke: Palgrave (forthcoming) 